\title{
An Analysis of the Determinants of Voluntary Structural Capital Disclosure by Listed French Companies
}

\author{
Inès Kateb ${ }^{1}$ \\ ${ }^{1}$ Higher Institute of Accountancy and Entrepreneurial Administration, Manouba University, Manouba, Tunisia \\ Correspondence: Inès Kateb, Higher Institute of Accountancy and Entrepreneurial Administration, Manouba \\ University, Manouba, Tunisia. Tel: 216-98-934-918. E-mail: ines kateb@yahoo.fr
}

Received: April 11, 2012

Accepted: May 5, 2012

Published: June 1, 2012

doi:10.5539/ijbm.v7n11p95

URL: http://dx.doi.org/10.5539/ijbm.v7n11p95

\begin{abstract}
This paper analyzes the characteristics of voluntary structural capital disclosure and points out the factors explaining the disclosure of such information, based on a sample of French companies belonging to the SBF 120 and observed in 2006.

Using manual content analysis, the study shows that firms provide more information on innovation capital with emphasizing on the narrative and descriptive forms. The results confirm that ownership structure, size, debts and the weight of activated goodwill are the determinants of voluntary structural capital disclosure. However variables apprehending the legitimacy's level of the firm and the interest in its stakeholders' pressure seem to be not significant in explaining the level of this disclosure.

Accordingly, the structural capital communication strategy does not meet the needs of legitimization that fit into a vision of corporate citizenship, but in order to mitigate some agency costs and solve the inadequacy of financial reporting.
\end{abstract}

Keywords: structural capital, voluntary disclosure, determinants, France

\section{Introduction}

In the new economy, companies have increasingly realized that the competence of men and work organization are the keys of growth and value creation. Indeed, the firms have become attentive to the need for investments in intangible activities to improve performance and competitivity.

Edvinsson and Malone (1997) are pioneers in working with intellectual capital. They defined it as the total stocks of all intangible assets and capabilities in a firm, which can create values or competitive advantages. According to the authors, intellectual capital is the sum total of its Human capital, Structural capital and Relational capital.

Human capital and Relational capital cannot be owned, but have to be shared with employees, customers and suppliers. However, Structural capital can be owned and controlled by an organization. It means all that stays in the firm «once the employees leave places in the evening» (Organization for Economic Cooperation and Development (OECD), 2006).

Edvinsson and Malone (1997) divide Structural capital into organizational, process and innovation capital. Organizational capital includes the organization philosophy and systems for leveraging the organization's capability. Process capital includes the techniques, procedures, and programs that implement and enhance the delivery of goods and services. Innovation capital includes intellectual properties and intangible assets. Intellectual properties are protected by commercial rights such as copyright, patent and trademarks. Intangible assets are all of the other talents and theory by which an organization is run.

The international accounting standards have became mandatory since January 2005 in France. For listed companies, more detailed information on intangible assets are required than a local repository. However, such information relates only to intangible elements that respond to activation conditions such as identifiability and control. Bessieux-Ollier et al. (2006) confirm that IAS required so restrictive conditions that only a few intangibles are intended to be capitalized. This creates the phenomena of the invisible Balance sheet. Therefore, 
disclosing about the components of Structural capital such as organizational and process capital is a voluntary act that gives wide latitude to managers for choosing the communication strategy of the company. This leads us to ask the first question of our research: Why do French firms provide voluntary information on their Structural capital in their annual report?

Several studies have investigated intellectual capital disclosure (ICD). The majority of these studies were exploratory and descriptive (Guthrie \& Petty, 2000; Goh \& Lim, 2004; April et al., 2003; Abeysekera \& Guthrie, 2005; Olsson, 2001; Brennan, 2001; Bontis, 2003). Few authors have used regression models to explain the extent of voluntary ICD (Williams, 2001; Bozzolan et al., 2003; Firer \& Williams, 2003; Bukh et al., 2005).

Furthermore, no research, as best as we know, has tried to use the costs proprietary theory to examine the determinants of voluntary ICD (Verrechia, 1983; Darrough \& Stoughton, 1990; Gigler, 1994). Indeed, the interest of this theory is more pronounced for disclosure on elements of differentiation such as knowledge and expertise.

In France, Ding and Stolowy (2002) examined the factors explaining voluntary disclosure on R\&D which is one component of structural capital. No previous research has rigorously studied the determinants of voluntary ICD and structural capital disclosure (SCD) within French firms. Consequently, more empirical studies are needed to understand how and why managers disclosure on intangibles.

Recent studies have examined empirically the relationship between the extent of voluntary ICD and the stock market value (Lev, 2002; Gerpott et al., 2008; Orens et al., 2009). The concept of shareholder value seems to be very limited. The performance of the firm is not restricted to create value for only shareholders but to optimize also the interest of all stakeholders who provide the firm the necessary resources for its continuity. Although the components of intellectual capital affect a variety of stakeholders and the link between social responsibility and the creation of intangible assets, no study has examined whether the ISD can be a process of legitimating which allows the firm to manage stakeholders' pressures.

Therefore, a second question follows: is this voluntary SCD responds to the needs of legitimization that fit into a vision of corporate citizenship or provided in order to reduce some agency costs information asymmetry?

To answer these questions, we first explored the level, nature and structure of structural capital information by analyzing the annual reports of a sample of French companies composing the SBF 120 index. We tried to identify, in a second step the determinants of voluntary Structural capital disclosure by focusing on the relationship between the amount of information disclosed and factors related to the firm and the environment in which it operates.

To achieve this, the present paper is organized as follows: a second section presenting the theoretical framework and the study's hypotheses; a third section devoting to methodology, including the method of content analysis and a fourth section presenting results and discussion.

\section{Review of the Literature and Hypotheses}

\subsection{Review of the Literature}

Several incentives have been reported in the literature in order to explain the extent of voluntary disclosure. In this study, we have classified these incentives into two different approaches: shareholder's approach and stakeholder's approach.

\subsubsection{Voluntary SCD According Shareholder's Approach: the Argument of Financial Utility}

According to the shareholder's approach, which is fundamentally defined by the firm's relations with its shareholders, the factors affecting the level of voluntary SCD are justified by agency theory and signalling theory, which are based on the hypothesis of asymmetric information stating that managers have more or better information than the stock market. Indeed, these theories attribute to financial information two different aspects: a contractual aspect, when the information is used to control external and internal contracts, and a predictive aspect, when the information is used by investors to improve their predictions concerning the future of the company (Raffournier \& Dumontier, 1989).

Separating ownership/control leads to conflicts of interest between managers and shareholders. Fama and Jensen (1983) argue that ownership structure determines the importance of these conflicts. Indeed, in closely held companies, the risk of wealth transfer would be limited due to the small number of shareholders. However, in widely held firms, leaders are required to reduce information asymmetry and to make their action transparent by disclosing more information to decrease conflicts of interest. 
Prior studies have showed a negative association between ownership concentration and the extent of voluntary ICD (Oliveira et al., 2006; Li et al., 2008; Williams \& Firer, 2003) in Portuguese, British and Singaporean firms

Jensen and Meckling (1976) confirm that agency costs increase with firm's size which leads to a positive relationship between the size and the extent of voluntary disclosure (Chow \& Wong-Boren, 1987; Saada, 1995). Numerous studies have found a positive and significant effect of firm size on voluntary ICD in UK, Hong Kong, Australia and Portugal (Bozzolan et al., 2006; Petty \& Cuganesan, 2005; Guthrie et al., 2006; White et al., 2007; Oliveira et al., 2006). Whereas, Williams (2001) has found size as an insignificant factor for British companies.

Jensen and Meckling (1976) argue that the agency costs are higher for companies with higher levels of debt. By voluntary disclosure, managers can decrease these costs (Fama \& Miller, 1972). Several studies have confirmed a positive relationship between debt and the extent of voluntary disclosure (Hossain et al., 1994). However, some others have not found a significant association (Wallace et al., 1994).

Concerning ICD, the results of previous studies are conflicting. While in Australia, Woodcock and Whiting (2009) and White et al. (2007) confirmed a positive relationship between leverage and the level of intellectual capital disclosure, Oliveira et al. (2006) have not found any relationship by analyzing a sample of Portuguese companies.

According to signalling theory, the most profitable companies provide the market with more and better information in order to signal to send specific signals and messages to the public (Salancik \& Meindl, 1984; Brown \& Deegan, 1999, cited by Li et al. 2008). Under this theoretical framework, voluntary SCD is considered as a signalling mechanism allowing managers to reduce adverse selection and capital cost.

Some studies have indicated that companies, in Spain and Singapore, disclosure more intellectual capital information to signal to the market their real value and growth potential (Garcia-Meca et al., 2005; Williams \& Firer, 2003), while other studies have showed no relationship at all (Williams, 2001).

\subsubsection{Voluntary SCD According Stakeholder's Approach: the Argument of Legitimization}

Within a second stakeholder's approach, where company interacts with a variety of actors other then shareholders, the voluntary SCD is based on two theories, widely used by authors to explain the disclosure on social responsibility (Damak-Ayadi, 2004; Roberts, 1992). The first one is legitimacy theory, in which firms constantly seek to prove that they work within the bounds and norms of their respective societies and try to ensure that their activities are perceived as "legitimate" (Deegan, 2002). The second one is stakeholder theory, which emphasizes the role of stakeholders in the determination of the communication strategy (Mitchell et al., 1997; Damak-Ayadi \& Pesqueux, 2003; Mercier, 2001).

Consequently, voluntary ICD provides firms with a chance to appear legitimate and avoid costs from non-legitimacy (Deegan \& Unerman, 2006; Beattie \& Thomson, 2007, cited by Li et al., 2010).

\subsection{Formulation of Hypotheses}

\subsubsection{Ownership Structure}

In UK, Zourarakis (2009) found a significant negative relationship between ownership structure measured by the number of shareholders holding more than 3\% of capital and the level of voluntary SCD. In France, Depoers (1999) argues that ownership structure affects the level of disclosure. The author confirms that voluntary disclosure can control and decrease the agency costs. Consequently, we hypothesize H1 that:

There is a negative association between managerial ownership concentration and the level of voluntary SCD.

\subsubsection{Size}

A second hypothesis arising from the agency theory indicating that bonding costs are expected to increase with size. According to Jensen and Meckling (1976), control (monitoring) becomes more difficult and expensive in large firms. Several authors have confirmed a positive association between company size and the level of voluntary ICD (Bozzolan et al. 2003; Williams \& Firer, 2003; Bozzolan et al., 2006; Petty \& Cuganesan, 2005; Guthrie et al., 2006; White et al., 2007; Oliveira et al., 2006). Concerning SCD, Zourarakis (2009) confirmed a positive association between size and level of voluntary disclosure for British companies. Therefore, we propose to test the following hypothesis $\mathrm{H} 2$ :

There is a positive association between size and the level of voluntary SCD.

\subsubsection{Debt}

In view of our theoretical developments, firms provide more information to mitigate agency problems between shareholders and creditors which increase with debt. However, a number of studies supply that disclosure has a 
negative impact on the cost of equity capital (Diamond \& Verrecchia, 1991; Lambert et al., 2007). Therefore, disclosure may raise the level of equity financing.

Kang and Gray (2011) show that debt is negatively associated with the extent of voluntary ICD in their study based on a sample of top 200 emerging market companies. Zourarakis (2009) proves no association between debt and the level of SCD. In France, Ding and Stolowy (2002) found that debt is not a determinant of voluntary $R \& D$ disclosure. In view of these inconclusive results, we propose the following non-directional hypothesis H3:

There is an association between debt and the level of voluntary SCD.

\subsubsection{Performance}

Garcia-Meca et al. (2005) showed that efficient Spanish firms (with a higher ROE) provide more information on intellectual capital than others. However, other studies have confirmed a negative relationship between profitability and the level of voluntary ICD (Firer \& Williams, 2003). Sonnier et al. (2007) confirm that if firms realize a good performance, the managers are required to reduce the level of disclosure in order to hide strategic information and maintain a competitive advantage. On the other hand, Skinner (1994) states that less profitable firms may disclose more information to give details about reasons for negative performance, to evade severe depreciation of share capital and to reassure the market about future growth.

Zourarakis (2009) showed that firm's performance (measured by ROA and ROE) is not a determinant of voluntary SCD. For this we will verify, in French context, the following hypothesis H4:

There is positive association between performance and the level of voluntary SCD.

\subsubsection{Age}

Stinchcombe (1965, cited by Chabaud et al., 2005) suggested that young firms are less legitimate than the older. Haniffa and Cooke (2002, cited by Woodcock \& Whiting, 2009) confirm that young organizations will try to reduce scepticism and amplify investors confidence who judge them as riskiest firms. While, Li et al. (2008) have confirmed a negative relationship between firm's age and the level of ICD, White et al. (2007) confirmed a positive one in Australian context. Woodcock and Whiting (2009) found no association between these two variables, thing which is confirmed by Bukh et al. (2005) in Denmark. So far, no previous research has studied the impact of age on the level of voluntary SCD. Therefore, we hypothesize H5 that:

There is an association between firm's age and the level of voluntary SCD.

\subsubsection{Listing Status}

Many studies showed that listing on foreign stocks markets increases the level of voluntary intellectual capital disclosure (Oliveira et al., 2006; Entwistle, 1999; Ding \& Stolowy, 2002). Indeed, a higher level of information could be attributed to regulatory differences between countries. Compared to those of continental countries, the Anglo-Saxon markets are more developed and their disclosure obligations are more restrictive. Therefore, we propose to test the following hypothesis H6:

Firms listed on both French and American stock markets publish more information on structural capital than those listed on only French stock market.

\subsubsection{Pressure of Stakeholders}

Stakeholder theory advances that to exist, firm needs the approval of the stakeholders and must adapt its activities to gain their support. Therefore, voluntary SCD allows the firm to establish a dialogue and respond to pressure of many social actors (Roberts, 1992; Damak-Ayadi, 2004). So we suppose to verify the following hypothesis $\mathrm{H} 7$ :

There is positive association between interest in the pressure of stakeholders and the level of voluntary SCD.

\subsubsection{Type of Industry}

Entwistle (1999) and Ding and Stolowy (2002) confirmed a positive association between belonging to a high-tech sector and the level of disclosure on the R\&D. Moreover, Sujan and Abeysekera (2007), Williams (2001), Woodcock and Whiting (2009), Oliveira et al. (2006) found that for companies belonging to a high-tech sector, the voluntary intellectual capital disclosure is higher than others. Thus we assume to test the following hypothesis $\mathrm{H} 8$ :

Firms belonging to a high-tech sector publish more information on structural capital than others. 


\subsubsection{Proprietary Costs}

Proprietary costs theory states that companies limit voluntary disclosure because of proprietary costs, such as preparation and competitive costs (Clinch \& Verrechia, 1997). Dye (1985) confirmed that disclosure reduces the value of cash flows since it generates indirect costs associated with the use of harmful private information by competitors of the company. FASB (2001) showed that intellectual capital disclosure is not very frequent because of costs related to measure problems of intangible assets and to reveal strategic information to competitors.

The literature review shows an absence of studies examining the relationship between levels of proprietary costs and voluntary SCD. This leads us to propose our last hypothesis H9:

There is negative association between the intensity of competition and the level of voluntary SCD.

\section{Methodology}

\subsection{Sample and Analysis Period}

In the beginning, our sample consists of firms belonging to the SBF 120 (Société des Bourses Françaises 120 Index). The index is based on the 120 most actively traded stocks listed in Paris. It includes all 40 firms in the CAC 40 index plus 80 additional firms listed on the Premier Marché and Second Marché under Euronext Paris and among the top 200 French companies classified by market capitalization. The choice of the companies having the highest market capitalization was useful for three reasons. First, most studies dealing with the voluntary ICD was based on multinationals and large firms (Escaffre, 2002). Second, these firms are characterized by the importance of their intangible elements which are not included in the financial statements but incorporated into the stock market value. Finally, these companies need to publish more information to obtain financial resources at lower costs (Bessieux-Ollier, 2002).

From this sample, we excluded banks, insurance companies, credit companies, holding companies because of their specific activities and their rules of reporting. We chose to analyze the annual report because it remains the favourite communication support due to its large degree of credibility (Neu et al., 1998), wide distribution (Mikol, 2000), coherence (Lang \& Lundholm, 1993) and regular production (Gray et al., 1995). The annual reports were downloaded from the websites of selected firms.

To obtain the maximum of variance in the distribution of firms' scores, we eliminated firms that provided their annual reports as reference documents. This limits our sample to 55 companies (Appendix A).

Concerning the period of the analysis, we focused on annual reports for the year 2006, after the adoption of international financial reporting standards (IFRS). Most previous studies focusing on voluntary intellectual capital disclosure were extended to only one year (White et al., 2007; Sujan \& Abeysekera, 2007; Oliveira et al., 2006; Guthrie et al., 2006; Bozzolan et al., 2003). This is based on the stability of the communication policy of firms over time and confirmed in several studies (Healy et al., 1999; Botosan, 1997).

\subsection{Variables and Model}

\subsubsection{The Dependent Variable: the Level of Voluntary SCD}

Measuring the level of voluntary SCD was based on manual content analysis (Li et al., 2008; White et al., 2007; Guthrie et al., 2006; Bozzolan et al., 2003). This method needs identification of categories and the choice of unit of analysis.

The categories used for classification and counting of structural capital words are taken from a list of items developed by Guthrie and Petty (2000). Their research paper is one of the earliest pioneering studies to examine intellectual capital disclosure practices. They have employed a list developed from Sveiby's (1997) model. However, we adapted this list to our French context by the use of "semi-formatted" content analysis in which categories must come from two sources: some general knowledge (literature) and the document itself. Therefore, we added two items: "innovation" and "R\&D". The final list relating to SCD consists of 10 items:
- Patents
- Copyrights
- Trademarks
- Innovation
- $\quad$ R\&D
- Managerial Philosophy 
- Corporate Culture

- Management process

- Information Systems

- Networked Systems.

Voluntary SCD is beyond the requirements of accounting standard and the legal framework. We have considered only the narrative / text (quantitative and qualitative). According to Beattie et al. (2002, cited by Kang \& Gray, 2011) this form contains almost all information voluntarily disclosed in the annual reports. Thus, the narratives analyzed in this paper include CEO's review, management report, sustainability report (if it is part of the annual report), sections on social responsibility and the captions from pictures. We have excluded financial statements and auditor's report. Consequently, disclosures required by IAS 38 and included in financial statements such as amortization rate, method used for each class of intangible assets and R\&D expenditure are excluded.

In this study, the sentence was selected as a coding unit since it is an independent clause containing a coherent idea (Zeghal \& Ahmed, 1999). Concerning the unit of measurement, several authors have used the sentence to identify the information disclosed on R\&D (Ding \& Stolowy, 2002; Entwistle, 1999). However, during our content analysis, we found that in most analyzed annual reports, a single sentence contains frequently several categories. Accordingly, we considered that the word (or words) placed in a sentence is the best unit to count the appearance of each item in the annual report since it minimizes the subjectivity of coders and gives a robust measure of the quantity of disclosure (Krippendorff, 1980). Li et al. (2008) advance that "The use of dichotomous procedure in scoring the instrument for the disclosure index has been criticized by some because it treats disclosure of one item (regardless of its form or content) as being equal, and does not indicate how much emphasis is given to a particular content category".

To check the reliability of our content analysis results, we used the procedure of Bozzolan et al. (2003) which refers to the three dimensions of reliability (accuracy, reproducibility and stability) cited by Krippendorff (1980).

\subsubsection{Model and Independent Variables}

The dependent variable, measured by the number of words (or groups of words) disclosed on structural capital is a count variable which can take only non-negative integers. Count variables are often treated as though they are continuous and the linear regression model is applied, which can result in inefficient, inconsistent, and biased estimation.

Opportunely, there is a variety of models that deal explicitly with the characteristics of count data (Long, 1997). Poisson model and binomial negative model, which make use of integrated nature of the data, are the more appropriate (Zeghal et al., 2007).

Model to be estimated is:

$$
\begin{gathered}
L n\left[E\left(I N F_{-} C S\right)\right]=\beta 0+\beta 1 P \_D I R+\beta 2 L O G \_T A+\beta 3 E N D T+\beta 4 Q \_T O B I N+\beta 5 R O E+\beta 6 A G E+\beta 7 \\
C O T \_A M+\beta 8 P P C+\beta 9 P P D+\beta 10 H T+\beta 11 P \_C C E+\beta 12 I N C \_A T+\beta 13 G D W \_A T+\varepsilon
\end{gathered}
$$

Where:

INF_CS: Number of words or groups of words disclosed on the structural capital;

P_DIR: The part of the capital held by the managers;

LOG_TA: The log there bases 10 of the active accountant;

ENDT: Long-term liabilities / Equity capitals;

Q_TOBIN: [Market capitalization + book value of debts] / Active accountant;

ROE: Net profit / Equity capitals;

AGE: Age of the firm calculated since its creation until year 2006;

COT_AM: Dummy taking 1 if firm is listed on French and American stock markets and 0 otherwise;

PPC: Number of contractual stakeholders mentioned in the president's message;

PPD: Number of diffuse stakeholders mentioned in the president's message;

HT: Dummy taking 1 if firm operates in a high-tech sector and 0 otherwise;

P_CCE: The number of rivals operating in the same sector;

INC_AT: Intangible assets; 
GDW_AT: Goodwill/total assets

\section{Results and Discussion}

The goal of the current study is double: explore, firstly, level, form and structure of voluntary SCD and identify, secondly, its determinants. To do this, we adopted a methodology composed by two types of analysis: descriptive/exploratory and multivariate analysis.

\subsection{Results of Descriptive Statistics}

Figure 1 shows the volume of information disclosed on structural capital for each firm composing the sample.

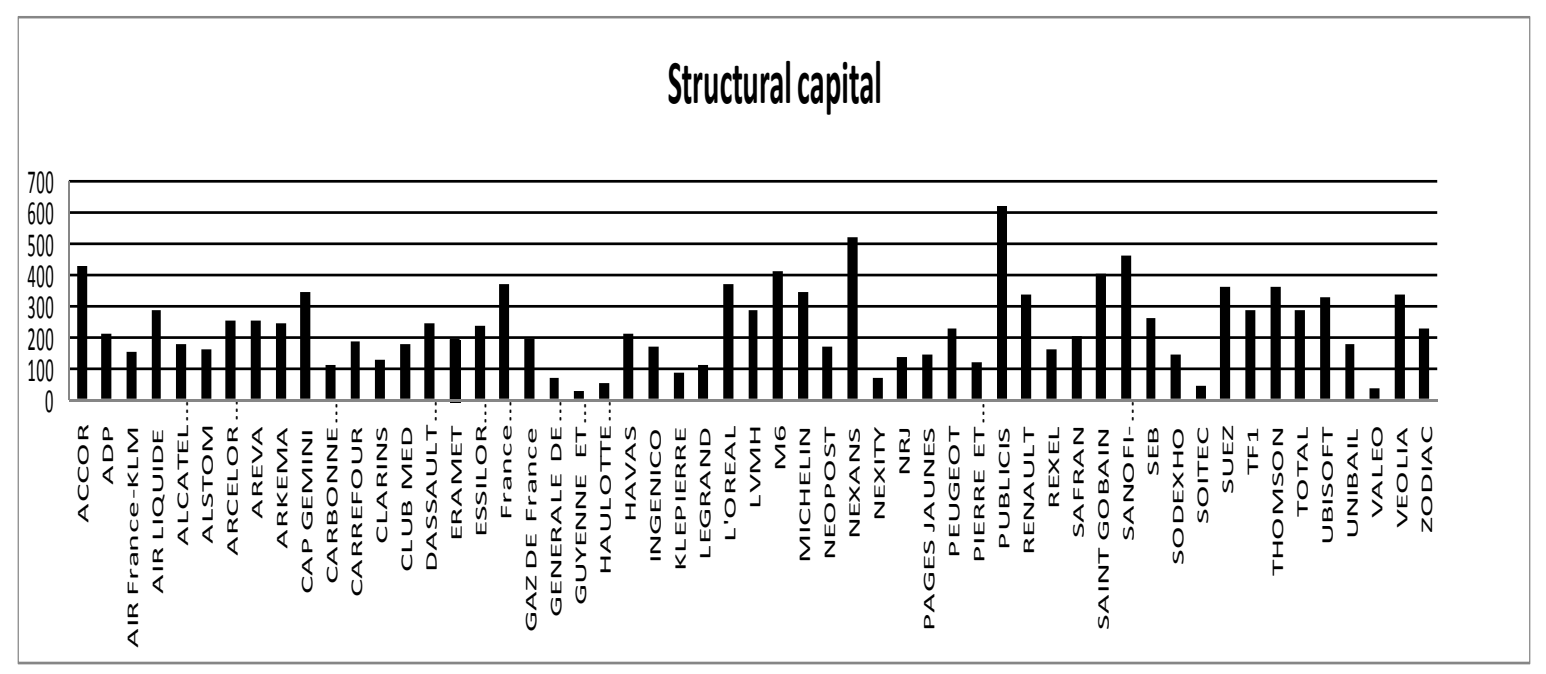

Figure 1. The level of SCD

In spite of the adoption of IFRS which aim to improve and standardize the content of financial reporting, we find that all firms proceed to the voluntary disclosure. Figure 1 shows that its volume appears highly variable between firms. This heterogeneity in communication policy affects comparability inter and intra companies. Consequently, IFRS provide only part of the information needed by investors.

The exploratory analysis revealed different forms of SCD: narration: qualitative/descriptive and quantitative, graph, table and picture. Figure 2 shows the different forms of SCD and their importance.

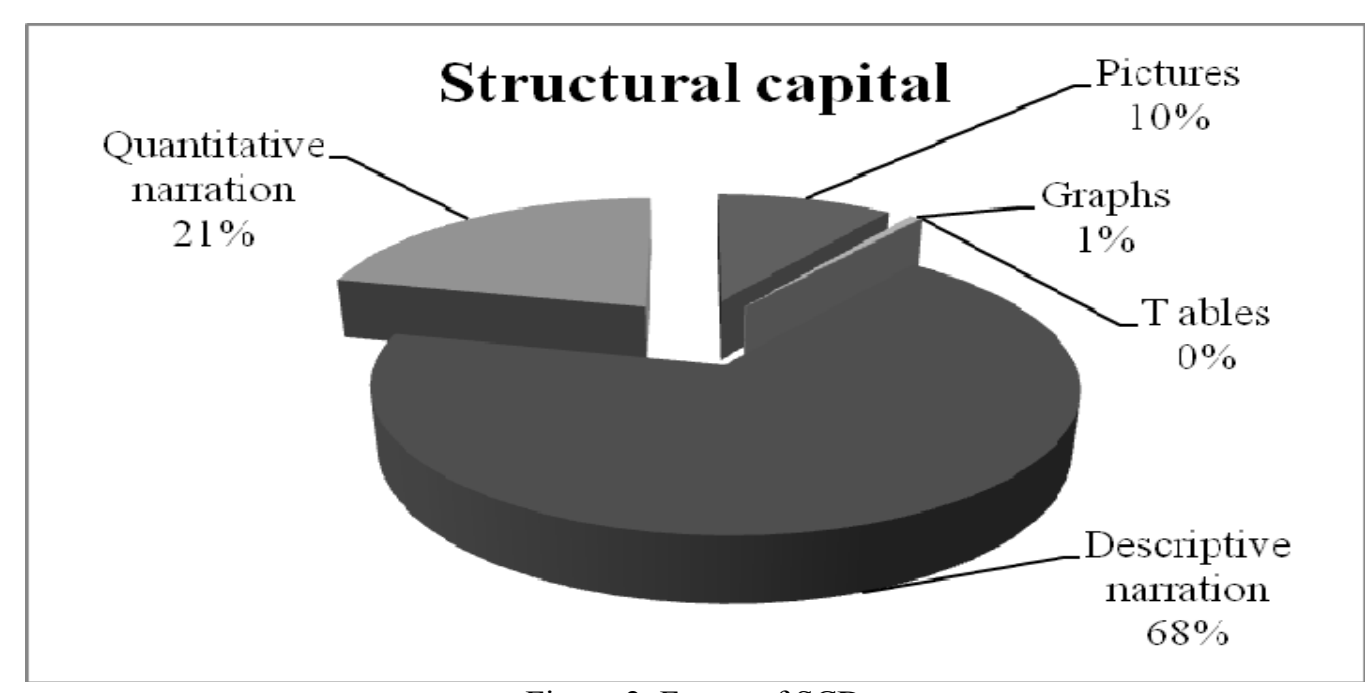

Figure 2. Forms of SCD 
As shown in Figure 2, descriptive narration form represents $68 \%$ of total disclosure. However, the quantitative form does not exceed $22 \%$ of same total: $21 \%$ concerning quantitative narration, $1 \%$ concerning graphs and insignificant percentage ( $0 \%$ ) concerning tables. Pictures form represents $10 \%$ of total disclosure.

These observations fulfill with many previous studies which confirming the predominance of descriptive narration form (Brennan, 2001; Guthrie \& Petty, 2000).

Table 1 illustrates descriptive statistics of each item composing the list and its frequency of apparition in annual reports.

Table 1. The structure of SCD

\begin{tabular}{llll}
\hline & Mean & Variance & frequency \\
\hline 1-Patents & 1.836 & 8.731 & $50.91 \%$ \\
2- Copyrights & 0.163 & 1.176 & $3.64 \%$ \\
3-Trademarks & 30.781 & 1712.544 & $90.91 \%$ \\
4-Innovation & 38.145 & 426.422 & $100 \%$ \\
5-R\&D & 31.654 & 951.267 & $94.55 \%$ \\
6- Managerial Philosophy & 46.49 & 783.847 & $100 \%$ \\
7- Corporate Culture & 6.854 & 69.645 & $89.09 \%$ \\
8- Management process & 20.49 & 492.624 & $92.73 \%$ \\
9-Information systems & 34.6 & 1297.356 & $96.36 \%$ \\
10- Networked Systems & 21.636 & 998.902 & $90.91 \%$ \\
Structural capital & $\mathbf{2 3 2 . 6 1 8}$ & $\mathbf{1 5 9 9 3 . 7 9 5}$ & $\mathbf{1 0 0 \%}$ \\
\hline
\end{tabular}

As shown in Table 1, "Innovation" and "Managerial Philosophy" are disclosed in all annual reports. However, few companies (3.64\%) disclose on "Copyrights".

Figure 3 shows the structure of voluntary SCD.

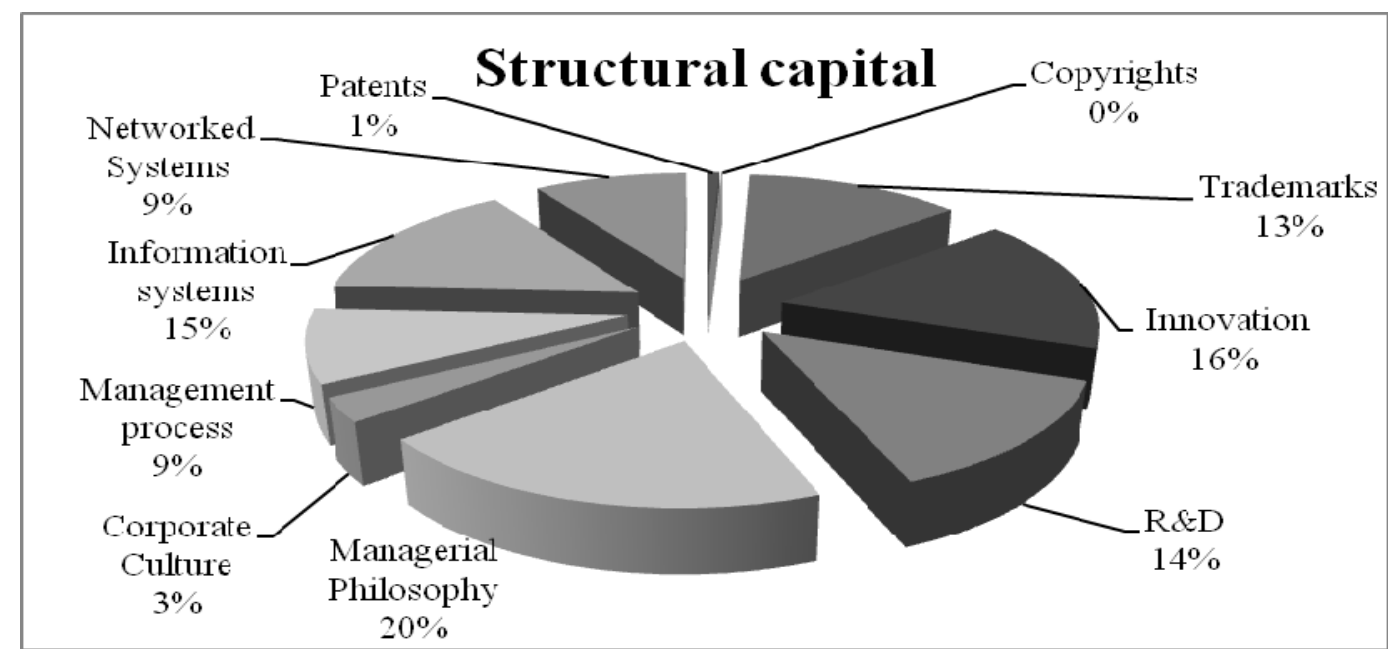

Figure 3. Structure of SCD

Based on the classification of structural capital provided by Edvinsson and Malone (1997), Figure 3 shows that firms disclose more about the innovation capital (44\% of total disclosure), then process capital and lastly the organizational capital. 
Descriptive statistics of quantitative and qualitative independent variables are summarized in tables 2 and 3 respectively.

Table 2. Descriptive statistics of quantitative variables

\begin{tabular}{lllll}
\hline Variables & Minimum & Maximum & Mean & Variance \\
\hline P_DIR & 0 & 0.550 & 0.067 & 0.013 \\
LOG_TA & 2.645 & 5.022 & 3.837 & 0.473 \\
ENDT & -0.945 & 2.755 & 0.813 & 0.426 \\
Q_TOBIN & 0.967 & 8.464 & 1.772 & 1.154 \\
ROE & -0.144 & 0.511 & 0.140 & 0.010 \\
AGE & 1 & 341 & 64.763 & 3483.22 \\
PPC & 1 & 5 & 3.618 & 1.129 \\
PPD & 0 & 5 & 1.818 & 1.267 \\
P_CCE & 1 & 22 & 3.527 & 11.068 \\
INC_AT & 0 & 0.433 & 0.082 & 0.009 \\
GDW_AT & 0 & 0.455 & 0.150 & 0.015 \\
\hline
\end{tabular}

Table 3. Descriptive statistics of qualitative variables

\begin{tabular}{llll}
\hline Variables & Modality & Frequency & Percentage \\
\hline HT & 0 & 32 & $58.18 \%$ \\
& 1 & 23 & $41.81 \%$ \\
COT_AM & 0 & 43 & $78.18 \%$ \\
& 1 & 12 & $21.81 \%$ \\
\hline
\end{tabular}

As shown in Table 2, turning to the means of dependant variables, we observe the part of the capital held by the managers, debt ratio, Tobin's $\mathrm{Q}$ and ROE to be $0.067,0.813,1.772$ and 0.14 respectively. The means for age, Number of contractual and diffuse stakeholders mentioned in the president's message and rivals operating in the same sector are $64.763,3.618,1.818$ and 3.527 respectively. It can be seen in the table 3 that high-tech French firms and those listed in an American stock markets represent $41.81 \%$ and $21.81 \%$ of sample respectively.

\subsection{Results of Multivariate Analysis}

Before multivariate analysis, we have verified the independence of variables to be ensured of absence of multicollinearity problems that may prejudice our results (Appendix B).

Firstly, the model is estimated by employing the Poisson regression technique. If an over-dispersion is found, the use of the negative binomial distribution is more appropriate than the Poisson (Long, 1997). The negative binomial regression model is an extension of the Poisson regression model that allows the variance of the process to differ from the mean.

Table 4 presents the estimated Poisson regression model and results of over-dispersion tests (Deviance and Pearson Chi-Square). 
Table 4. Results of poisson regression model

\begin{tabular}{llll}
\hline & $\boldsymbol{\beta}$ & $\mathbf{Z}$ & Signification \\
\hline Constant & 4.126047 & 43.04 & 0.000 \\
P_DIR & -0.9643817 & -9.00 & 0.000 \\
LOG_TA & 0.3327304 & 16.61 & 0.000 \\
ENDT & -0.3041951 & -14.19 & 0.000 \\
Q_TOBIN & -0.0631424 & -5.29 & 0.000 \\
ROE & 0.1160413 & 1.14 & 0.254 \\
AGE & 0.0010993 & 7.04 & 0.000 \\
COT_AM & -0.1922698 & -7.19 & 0.000 \\
PPC & 0.0392107 & 3.73 & 0.000 \\
PPD & 0.0518615 & 7.41 & 0.000 \\
HT & 0.0612753 & 2.63 & 0.009 \\
P_CCE & -0.0165308 & -4.59 & 0.000 \\
INC_AT & 0.4006453 & 3.68 & 0.000 \\
GDW_AT & 1.033493 & 11.33 & 0.000 \\
Deviance (sig.) & $2454.628\left(0.000^{* * *}\right)$ & & \\
Pearson KHI2 (sig.) & $2312.246\left(0.000^{* * *}\right)$ & & \\
\hline
\end{tabular}

*** Significant at level of $1 \%$

As shown in Table 4, data are over-dispersed. Therefore, the Poisson regression is not appropriate and the use of negative binomial regression is required. Table 5 presents the estimated negative binomial regression model.

Table 5. Results of negative binomial regression model

\begin{tabular}{llll}
\hline & $\boldsymbol{\beta}$ & $\mathbf{Z}$ & Signification \\
\hline Constant & 3.906738 & 5.61 & 0.000 \\
P_DIR & -1.515804 & -2.28 & $0.023^{* *}$ \\
LOG_TA & 0.3524479 & 2.44 & $0.015^{* *}$ \\
ENDT & -0.3219234 & -2.26 & $0.024^{* *}$ \\
Q_TOBIN & -0.0779357 & -0.98 & 0.326 \\
ROE & 0.2225523 & 0.35 & 0.727 \\
AGE & 0.0013172 & 1.05 & 0.295 \\
COT_AM & -0.2628047 & -1.31 & 0.189 \\
PPC & 0.077551 & 0.93 & 0.350 \\
PPD & 0.0674384 & 1.23 & 0.220 \\
HT & 0.0098912 & 0.06 & 0.952 \\
P_CCE & -0.0191925 & -0.80 & 0.423 \\
INC_AT & 0.9047057 & 1.09 & 0.274 \\
GDW_AT & 1.168392 & 1.79 & $0.073 *$ \\
KHI2 (sig.) & $22.35\left(0.05^{* *}\right)$ & & \\
Cragg and Uhler's $\mathbf{R}^{2}$ & 0.355 & & \\
\hline
\end{tabular}


Negative binomial regression shows that coefficients associated with variables measuring the managerial ownership (P_DIR), size (LOG_TA) and debt (ENDT) are significant. These results allow us to validate H1, H2 and $\mathrm{H} 3$ (hypotheses fit into the context financial utility's argument). However, the multivariate analysis shows that the performance of the firm (Q TOBIN and ROE), age (AGE), listing status (COT_AM), interest in the pressure of stakeholders (PPC and PPD), the industry (HT) and competitive pressure (P_CCE) are not explanatory factors of the voluntary SCD. This leads us to reject $\mathrm{H} 4, \mathrm{H} 5, \mathrm{H} 6, \mathrm{H} 7, \mathrm{H} 8$, and $\mathrm{H} 9$.

\subsection{Discussion}

Here we summarize and discuss the effect of independent variables on the volume of voluntary SCD.

Managerial ownership concentration shows a significant negative association with the volume of SCD. This supports our hypothesis H1 and is in line with the findings of Williams and Firer (2003), Oliveira et al. (2006), Li et al. (2008) in Singapore, Portugal and UK. Based on agency theory, when the functions of management and ownership are merged, the monitoring motivation for disclosure are reduced (O'Sullivan, 2000, cited by Li et al., 2008).

Our results support the hypothesis $\mathrm{H} 2$ that there is a positive association between size and the level of voluntary SCD. This is in accordance with prior ICD studies (Williams \& Firer, 2003; Petty \& Cuganesan, 2005; Guthrie et al., 2006; White et al., 2007; Oliveira et al., 2006) and SCD studies (Zourarakis, 2009).

In addition to reducing agency costs, the positive association of the size found other justifications. The first is that disclosure has a cost and that larger the firm is, more it is able to afford (Raffournier, 1995). The second is that large corporations are generally subjected to special attention from financial analysts and in order to maintain credibility, they have an incentive to be transparent and to report their position as market overvaluation. The third is based on stakeholder and legitimacy theory which announces that large firms are more prone to political pressures that small firms. Therefore greater disclosure allows managers to legitimize themselves and their activities.

The validation of hypotheses $\mathrm{H} 1$ and $\mathrm{H} 2$ confirms that voluntary SCD may be a mechanism that allows leaders to reduce information asymmetry, agency costs and therefore maximize the firm's market value.

Results show a negative relationship between debt and the level of voluntary SCD and support our hypothesis H3. This is in the opposite of the findings of Zourarakis (2009) in UK indicating that debt has not an impact on SCD. In fact, in contractual relationship between managers and shareholders, debt can be considered as a way to reduce agency costs as it promotes the convergence of interests of both contracting parties. In this sense, voluntary disclosure should decrease with debt. Otherwise, in French civil law countries, creditors have the strongest legal protection which leads to a developed banking system. Diamond (1991) suggests that banks have greater access to private information than other lenders (such investors) and rely less on public disclosure to reduce information asymmetry.

This negative association may also result from managers' retention of such information, because of the high risk of intangible investments. Indeed, this disclosure may cause the dissatisfaction of creditors and increase the financing cost (Roberts, 1992).

The regression results disprove an association between firm's performance and the level of voluntary SCD. This result confirms what found by Williams (2001) who showed no relationship between firm's performance and the level of voluntary intellectual capital. Similarly, Miller and Whiting (2008) and Brennan (2001) confirmed the absence of association between the "hidden value", a similar measure to Tobin's Q, and voluntary intellectual capital disclosure. The reject of this hypothesis H4 leads us to suggest that SCD cannot be considered as a signaling mechanism.

Regarding the argument of legitimacy, the age of the firm, the listing status and the interest in stakeholders' pressure are not determinants of SCD. This leads us to reject our hypotheses H5, H6 and H7. Indeed, contrary to social information, voluntary SCD has not as objective neither to establish a social dialogue nor to meet different stakeholders' expectations.

Younger firms do not tend to give more SCD. This is in conformity with the results of Haniffa and Cooke (2002) and Woodcock and Whiting (2009) for Malaysian and Australian firms. Furthermore, harmonization efforts and the convergence between U.S. GAAP and IFRS implies few differences in financial reporting between French firms listed on U.S. markets and French firms listed only on local market but adopted IFRS.

Type of industry (H8) seems to be not significant in explaining SCD. This corroborates the results of Guthrie et al. (2006) and Wong and Gardner (2005), concerning ICD, in Australia and New Zealand and it is inconsistent 
with the conclusions of Williams (2001), Woodcock and Whiting (2009), Oliveira et al. (2006) and Garcia-Meca et al. (2005). Li et al. (2008) confirm that these inconclusive findings "could be due to the lack of representativeness in sampling at sector level".

Our results reject the hypothesis $\mathrm{H} 9$ that there is a negative association between the intensity of competition and the level of voluntary SCD. This is in contradiction with the proprietary costs theory argument for French companies.

Although the results indicate no association between intangible assets' weight in the balance sheet and the level of voluntary SCD, they confirm a positive relationship between this disclosure and the weight of goodwill corresponding to intangible elements which are not capable of being individually identified and separately recognized due to the absence of reliable measurement and control criteria. This leads us to suggest that voluntary $\mathrm{SCD}$, essentially qualitative and descriptive, is chosen by managers in order to complete financial reporting and to address the inadequate accounting treatment of intangibles

\section{Conclusion}

The development of intangible resources and their contribution in the economic growth are clashed to the inability of financial reporting to reflect the real value of the firm. For this, many companies have preceded to non financial and voluntary disclosure which becomes an increasing need for stakeholders. However until now, there is not a consensus model homogenizing intangibles disclosure practices.

This paper tried to identify the determinants of voluntary SCD based on the contributions of contractual theories (agency theory) and socio-political theories (legitimacy theory). The study showed the prevalence of financial utility of voluntary disclosure. Indeed, firms publish on structural capital to increase the market value of the firm by reducing agency costs, information asymmetry and inadequacy of financial reporting.

Based on this research, several studies can be initiated in different contexts by examining other factors that may influence the level of voluntary relational and human capital disclosure by analyzing other communication supports.

\section{References}

Abeysekera, I., \& Guthrie, J. (2004). Human capital reporting in a developing nation. The British Accounting Review, 36, 251-268. http://dx.doi.org/10.1016/j.bar.2004.03.004

April, K. A., Bosma, P., \& Deglon, D. A. (2003). IC measurement and reporting: establishing a practice in SA mining. Journal of Intellectual Capital, 4(2), 165-180. http://dx.doi.org/10.1108/14691930310472794

Bessieux-Ollier C. (2002). Les déterminants culturels des choix comptables: le cas des éléments incorporels. $\mathrm{PhD}$ in Management Sciences, Paris: Paris Dauphine University.

Bessieux-Ollier, C., Lacroix M., \& Walliser, E. (2006). Le capital humain : approche comptable versus approche managériale. Revue internationale sur le travail et la société, 4(2), 25-57.

Bontis, N. (2003). Intellectual capital disclosure in Canadian corporations. Journal of Human Resource Costing and Accounting, 14, 9-20. http://dx.doi.org/10.1108/eb029076

Botosan, C. (1997). Disclosure level and the cost of equity capital. The Accounting Review, 72(2), 323-349.

Bozzolan, S., Favotto, F., \& Ricceri, F. (2003). Annual Italian intellectual capital disclosure, an empirical analysis. Journal of Intellectual Capital, 4(4), 543-558. http://dx.doi.org/10.1108/14691930310504554

Bozzolan, S., O'Regan, P., \& Ricceri F. (2006). Intellectual capital disclosure (ICD): A comparison of Italy and the UK. Journal of Human Resource Costing and Accounting, 10(2), 92-113. http://dx.doi.org/10.1108/14013380610703111

Brennan, N. (2001). Reporting intellectual capital in Annual Reports: evidence from Ireland. Accounting, Auditing and Accountability Journal, 14(4), 423-436. http://dx.doi.org/10.1108/09513570110403443

Bukh, P. N., Nielsen, C., Gormsen, P., \& Mouritsen, J. (2005). Disclosure of information on intellectual capital in Danish IPO prospectuses. Accounting, Auditing and Accountability Journal, 18 (6), 713-732. http://dx.doi.org/10.1108/09513570510627685

Chabaud, D., Ehlinger, S, \& Perret, V. (2005). Accompagnement de l'entrepreneur et légitimité institutionnelle: le cas d'un incubateur. from http://www.thomas-legrain.com/wp-content/documents/entrepreneuriat/accompagnement-entrepreneur-legit imite-institutionnelle-cas-incubateur.pdf 
Chow, C.W., \& Wong-Boren, A. (1987). Voluntary financial disclosure by Mexican corporations. The Accounting Review, 62(3), 533-541.

Clinch, G., \& Verrechia, R. E. (1997). Competitive disadvantage and discretionary disclosure in industries. Australian Journal of Management, 22(2), 125-137. http://dx.doi.org/10.1177/031289629702200201

Damak-Ayadi, S., \& Pesqueux, Y. (2003). La théorie des parties prenantes en perspective. Journée de Développement Durable et Entreprise conference, Angers, France.

Dammak-Ayadi, S. (2004). La publication des rapports sociétaux par les entreprises françaises. $\mathrm{PhD}$ in Management Sciences, Paris: Paris Dauphine University.

Darrough, M., \& Stoughton, N. (1990). Financial disclosure policy in an entry gam. Journal of Accounting and Economics, 12(1-3), 219-243.

Deegan, C. (2002). The legitimising effect of social and environmental disclosures? A theoretical foundation. Accounting, Auditing and Accountability Journal, 15(3), 282-311. http://dx.doi.org/10.1108/09513570210435852

Depoers, F. (1999). Contribution à l'analyse des déterminants de l'offre volontaire d'informations des sociétés cotées. PhD in Management Sciences, Paris: Paris Dauphine University.

Diamond, D.W. (1991). Monitoring and Reputation: The Choice between Bank Loans and Privately Placed Debt. Journal of Political Economy, 99, 689-721.

Diamond, D.W., \& Verrechia, R.E. (1991). Disclosure, liquidity and the cost of capital. Journal of Finance, 46, 1325-1359. http://dx.doi.org/10.2307/2328861

Ding, Y., \& Stolowy, H. (2002). Les facteurs explicatifs de la stratégie des groupes français en matière de communication sur les activités de R\&D. Finance Contrôle Stratégie, 6(1), 39- 62.

Dumontier, P., \& Raffournier, B. (1989). L'information comptable: pour qui? Pourquoi? Revue Française de Gestion, mars-avril-mai, 23-29.

Dye, R. (1985). Disclosure of non-proprietary information. Journal of Accounting Research, 23(1), 123-145.

Edvinsson, L., \& Malone, M. S. (1997). Intellectual Capital: Realizing Your Company's True Value by Finding Its Hidden Roots. HarperCollins Publishers, Inc., New York.

Entwistle, G.M. (1999). Exploring the R\&D Disclosure Environment. Accounting Horizons, 13(4), 353-385. http://dx.doi.org/10.2308/acch.1999.13.4.323

Escaffre, L. (2002). Contribution à l'analyse de l'offre d'information sur le capital intellectuel. $\mathrm{PhD}$ in Management Sciences, Paris: Paris Dauphine University.

Fama, E.F., \& Jensen, M.C. (1983). Separation of ownership and control. Journal of Law and Economics, 26(2), 301-325.

Fama, E.F., \& Miller, M. (1972). The Theory of Finance. Dryden Press, Hinsdale, IL.

Financial Accounting Standard Board (FASB). (2001). Improving Business Reporting: Insights into Enhancing Voluntary Disclosures. Retrieved from http://www.fasb.org/cs/BlobServer?blobcol=urldata\&blobtable=MungoBlobs\&blobkey=id\&blobwhere=11 75819611134\&blobheader=application\%2Fpdf

Firer, S., \& Williams, S.M. (2003). Association Between the ownership structure of Singapore publicly traded firms intellectual capital and Disclosures. Retrieved from http://www.research.smu.edu.sg/faculty/cgic/Research/Research_Papers/CGICResearchPaper7.pdf

Garcia-Meca, E., Perra I., Larran M., \& Martinez I. (2005). The explanatory factoring of intellectual capital disclosure to Financial Analysts. The European Accounting Review, 14(1), 63-94. http://dx.doi.org/10.1080/0963818042000279713

Gerpott, T.J., Thomas, S.E., \& Hoffmann, A.P. (2008). Intangible assets disclosure in the telecommunications industry. Journal of Intellectual Capital, 9(1), 37-61. http://dx.doi.org/10.1108/14691930810845795

Gigler, F. (1994). Self enforcing voluntary disclosures. Journal of Accounting Research, 32(2), 224-240. http://dx.doi.org/10.2307/2491283

Goh, P.C., \& Lim, K.P. (2004). Disclosing intellectual capital in company annual reports, evidence from Malaysia. Journal of Intellectual Capital, 5(3), 500-10. http://dx.doi.org/10.1108/14691930410550426 
Gray R.H., Kouhy, R., \& Lavers, S. (1995). Corporate Social and Environmental Reporting: a review of the literature and a longitudinal study of UK disclosure. Accounting, Auditing and Accountability Journal, 8(2), 47-77. http://dx.doi.org/10.1108/09513579510146996

Guthrie, J., \& Petty, R. (2000). Intellectual capital: Australian Annual Reporting practices. Journal of Intellectual Capital, 1(3), 241-51. http://dx.doi.org/10.1108/14691930010350800

Guthrie, J., Petty, R., \& Ricceri, F. (2006). The voluntary reporting of intellectual capital. Comparing evidence from Hong Kong and Australia. Journal of Intellectual Capital, 7(2), 254-271. http://dx.doi.org/10.1108/14691930610661890

Haniffa, R.M., \& Cooke, T.E. (2002). Culture, corporate governance and disclosure in Malaysian corporations. ABACUS, 38(3), 317-350. http://dx.doi.org/10.1111/1467-6281.00112

Healy, P.M., Hutton, A.P., \& Palepu, K.G. (1999). Stock performance and intermediation exchange Surrounding Sustained Increases in disclosure. Contemporary Accounting Research, 16(3), 485-520.

Hossain, M., Perera, M.B., \& Rahman, A.R. (1995). Voluntary disclosure in the annual report of New Zealand companies. Journal of International Financial Management and Accounting, 6(1), 69-87. http://dx.doi.org/10.1111/j.1467-646X.1995.tb00050.x

Jensen, M.C., \& Meckling, W.H. (1976). Theory of the firm: Managerial Behavior, agency costs and ownership structure. Journal of Financial Economics, 3(4), 305-360.

Kang, H., \& Gray, J. (2011). Reporting Intangible Assets: Voluntary Disclosure Practices of Top Emerging Market Companies. The International Journal of Accounting, 46(4), 402-423. http://dx.doi.org/10.1016/j.intacc.2011.09.007

Krippendorff, K. (1980). Content analysis: An introduction to its methodology. London: Sage Publications.

Lambert, R., Leuz, C., \& Verrecchia, R. (2007). Accounting Information, Disclosure, and the Cost of Capital. Journal of Accounting Research, 45(2), 385-420. http://dx.doi.org/10.1111/j.1475-79X.2007.00238.x

Lang, M., \& Lundholm, R.J. (1993). Corporate disclosure policy and analyst Behavior. The Accounting Review, 71(4), 467-492.

Lev, B. (1999). R\&D and Capital Markets. Journal of Applied Corporate Finance, 11(4), 21-35. http://dx.doi.org/10.1111/j.1745-6622.1999.tb00511.x

Lev, B. (2002). Mismeasurement of Intangibles and its Consequences. New York University, Stern School.

Li, J., Mangena, M., \& Pike, R. (2010). Intellectual Capital Disclosure Practices and Effects on the Cost of equity Capital: UK Evidence. T. J. International Ltd.

Li, J., Pike, R., \& Haniffa, R. (2008). Intellectual capital disclosure and corporate governance structure in UK $\begin{array}{lllll}\text { FIRMS. Accounting and Business } & \text { Research, }\end{array}$ http://dx.doi.org/10.1080/00014788.2008.9663326

Long, J. S. (1997). Regression Models for Categorical and Limited Dependent Variables. Thousand Oaks, CA: Sage.

Meek, G.K., Roberts, C.B., \& Gray, S.J. (1995). Factors Influencing voluntary annual report Disclosures by US, UK and continental European multinationals. Journal of International Business Studies, 26(3), 555-572.

Mercier, S. (1999). L'éthique dans les entreprises. Edition La découverte, Paris.

Mikol, A. (2000). L'information environnementale publiée par les sociétés du CAC 40 de 1992 à 1998 comparée à une information environnementale type. Revue Française de comptabilité, 322, 67-72.

Miller, J. C., \& Whiting, R. H. (2008). Voluntary Disclosure of Intellectual Capital in New Zealand Annual Reports and the "hidden value". Journal of Human Resource Costing \& Accounting, 12(1), 26-50. http://dx.doi.org/10.1108/14013380810872725

Mitchell, R. K., Agle, B. R., \& Wood, D. J. (1997). Toward a theory of stakeholder's identification and salience: defining the principles of who and what really counts. Academy of Management Review, 22(2), 833-886. http://dx.doi.org/10.5465/AMR.1997.9711022105

Neu, D., Warsame, H., \& Pedwell, K. (1998). Managing public impressions: environmental Disclosures in Annual Reports. Accounting, Organizations and Society, 23(3), 265-282. http://dx.doi.org/10.1016/S0361-3682(97)00008-1 
Oliveira, L. Rodrigues, L.L., \& Craig, R. (2006). Firm-specific determinants of intangibles reporting: evidence from the Portuguese stock market. Journal of Human Resource Costing and Accounting, 10(1), 11-33. http://dx.doi.org/10.1108/14013380610672657

Olsson, B. (2001). Annual Reporting Practices: Information about Human Resources in Corporate Annual Reports in Major Swedish Companies. Journal of Human Resource Costing and Accounting, 6(1), 39-52. http://dx.doi.org/10.1108/eb029071

Orens, R., Aerts, W., \& Lybaert, N. (2009). Intellectual capital disclosure cost of finance and firm value. Management Decision, 47(10), 1536-1554. http://dx.doi.org/10.1108/00251740911004673

Organization for Economic Cooperation and Development (2006). Intangible assets and value creation. Retrieved from www.oecd.org/dataoecd/53/18/36701585.pdf

Petty, R., \& Cuganesan, S. (2005). Voluntary Disclosure of Intellectual Capital by Hong Kong Countries: Examining Size, Industry and Growth Effects over Time. Australian Accounting Review, 15(2), 40-50.

Raffournier, B. (1995). The determinants of voluntary disclosure by Swiss listed financial companies. The European Accounting Review, 4(2), 261-280. http://dx.doi.org/10.1080/09638189500000016

Roberts, R.W. (1992). Determinants of corporate social responsibility disclosure. Accounting, Organizations and Society, 17(6), 595-612. http://dx.doi.org/10.1016/0361-3682(92)90015-K

Saada, T. (1995). Les déterminants des choix comptables: une étude des pratiques françaises et comparaison franco-américaine. Comptabilité, Contrôle, Audit, 1(2), 52-74.

Skinner, D. J. (1994). Why firms voluntarily disclose bad news. Journal of Accounting Research, 32(1), 38-60. http://dx.doi.org/10.2307/2491386

Sonnier, B., Carson, K. D., \& Carson, P. P. (2007). Accounting for Intellectual Capital: The Relationship between Profitability and Disclosure. The Journal of Applied Management and Entrepreneurship, 12(2), 3-14.

Sujan, A., \& Abeysekera, I. (2007). Intellectual Capital Reporting Practices of the Top Australian Firms. Australian Accounting Review, 17(2), 71-83. http://dx.doi.org/10.1111/j.1835-2561.2007.tb00445.x

Sveiby, K. E. (1997). The New Organizational Wealth, Managing and Measuring Knowledge-Based Assets. Berrett-Koehler Publishers, San Francisco.

Verrechia, R.E. (1983). Discretionary disclosure. Journal of Accounting and Economics, 5, 179-194. http://dx.doi.org/10.1016/0165-4101(83)90011-3

Wallace, R.S.O., Nasser, K., \& Mora, A. (1994). The relationship between the comprehensiveness of corporate annual reports and firm characteristics in Spain. Accounting and Business Research, 25(97), 41-53. http://dx.doi.org/10.1080/00014788.1994.9729927

Watson, A., Shrives, P., \& Marston, C. (2002). Voluntary Disclosure of Accounting Ratios in the UK. British Accounting Review, 34, 289-313. http://dx.doi.org/10.1006/bare.2002.0213

White, G., Lee, A., \& Tower, G. (2007). Drivers of voluntary intellectual capital disclosure in listed biotechnology companies. Journal of Intellectual Capital, 8(3), 517-537. http://dx.doi.org/10.1108/14691930710774894

Williams, S.M. (2001). Is intellectual capital performance and disclosure practices related? Journal of Intellectual Capital, 2(3), 192-203. http://dx.doi.org/10.1108/14691930110399932

Wong, M., \& Gardner, C.T. (2005). Intellectual Capital Disclosure: New Zealand Evidence. Paper presented at the Accounting and Finance Association of Australia and New Zealand (AFAANZ) conference, Australia.

Woodcock, J., \& Whiting, R.H. (2009). Intellectual Capital Disclosures by Australian Companies. Paper presented at the Accounting and Finance Association of Australia and New Zealand (AFAANZ) conference, Australia.

Zéghal, D., \& Ahmed, S.A. (1999). Comparison of social responsibility information: Media Used by Canadian disclosure firms. Accounting auditing and accountability Journal, 3(1), 38-53. http://dx.doi.org/10.1108/09513579010136343

Zeghal, D., Mouelhi, R., \& Louati, H. (2007). An Analysis of the Determinants of Research \& Development Voluntary Disclosure by Canadian Firms. The Irish Accounting Review, 14(2), 61-89. 
Zourarakis, N.S. (2009). Voluntary disclosure: Evidence from the U.K. Retrieved from http://publishing.eur.nl/ir/repub/asset/15574/Accountability_zourarakis.pdf

Appendix A: Distribution of sample firms across sectors

\begin{tabular}{lll}
\hline Sectors & Effective & \% in sample \\
\hline Aerospace and Defense & 2 & $3,63 \%$ \\
Automobile & 5 & $9,09 \%$ \\
Consumer goods & 2 & $3,63 \%$ \\
Chemicals, pharmaceuticals and health & 6 & $10,90 \%$ \\
Construction and building materials & 3 & $5,45 \%$ \\
Distribution & 2 & $3,63 \%$ \\
Electrical and electronic equipment & 12 & $21,81 \%$ \\
Entertainment and Hotels & 3 & $5,45 \%$ \\
Médias & 5 & $9,09 \%$ \\
Energy, Oil and Gas & 5 & $9,09 \%$ \\
Services & 6 & $10,90 \%$ \\
Computers and telecommunications & 4 & $7,27 \%$ \\
Total & $\mathbf{5 5}$ & $\mathbf{1 0 0} \%$ \\
\hline
\end{tabular}

Appendix B: The correlation matrix of explanatory variables

\begin{tabular}{|c|c|c|c|c|c|c|c|c|c|c|c|c|c|}
\hline Variables & P_DIR & LOG_TA & ENDT & Q TOBIN & ROE & AGE & COT_AM & PPC & PPD & HT & P_CCE & INC_AT & GDW_AT \\
\hline P_DIR & 1 & & & & & & & & & & & & \\
\hline LOG_TA & $-0,270$ & 1 & & & & & & & & & & & \\
\hline ENDT & $-0,193$ & 0,455 & 1 & & & & & & & & & & \\
\hline Q TOBIN & 0,098 & $-0,423$ & $-0,248$ & 1 & & & & & & & & & \\
\hline ROE & $-0,159$ & $-0,001$ & $-0,023$ & 0,300 & 1 & & & & & & & & \\
\hline AGE & $-0,155$ & 0,060 & 0,028 & $-0,100$ & $-0,005$ & 1 & & & & & & & \\
\hline COT_AM & $-0,229$ & 0,516 & 0,191 & $-0,216$ & $-0,028$ & 0,100 & 1 & & & & & & \\
\hline PPC & $-0,049$ & 0,191 & 0,258 & 0,006 &,- 0203 & $-0,254$ & 0,066 & 1 & & & & & \\
\hline PPD & $-0,226$ & 0,429 & 0,281 & $-0,145$ & 0,039 & 0,044 & 0,252 & 0,299 & 1 & & & & \\
\hline HT & $-0,035$ & $-0,125$ & 0,042 & 0,158 & $-0,195$ & $-0,226$ & $-0,002$ & 0,139 & 0,018 & 1 & & & \\
\hline P_CCE & $-0,055$ & $-0,048$ & $-0,103$ & $-0,126$ & $-0,159$ & 0,149 & $-0,080$ & 0,126 & $-0,034$ & 0,079 & 1 & & \\
\hline INC_AT & 0,005 & 0,205 & $-0,179$ & $-0,033$ & $-0,121$ & 0,009 & 0,263 & 0,028 & $-0,005$ & 0,109 & 0,08 & 1 & \\
\hline GDW_AT & 0,001 & $-0,025$ & 0,249 & 0,182 & $-0,044$ & 0,080 & 0,091 & $-0,023$ & $-0,018$ & 0,319 & 0,20 & 0,14 & 1 \\
\hline
\end{tabular}

Legend: P_DIR: The part of the capital kept by the leaders; $\mathbf{L O G}$ TA: The log there bases 10 of the active accountant; ENDT: Long-term liabilities / Equity capitals; $\boldsymbol{Q} \_$TOBIN: [Market capitalization + book value of debts] / Active accountant; ROE: Net profit / Equity capitals; $\boldsymbol{A G E}$ : Age of the firm calculated since its creation until year 2006; COT_AM: Dummy taking 1 if firm is listed on French and American stock markets and 0 otherwise; PPC: Number of contractual stakeholders mentioned in the president's message; PPD: Number of diffuse stakeholders mentioned in the president's message; HT: Dummy taking 1 if firm operates in a high-tech sector and 0 otherwise; $\boldsymbol{P}_{-} \boldsymbol{C C E}$ : The number of rivals operating in the same sector; INC_AT: Intangible assets; GDW_AT: Goodwill/total assets. 